\title{
Germination Behaviour of a Perennial Amaranthaceae of North Western Algeria (Oran): Arthrocnemum glaucum (Del.) Ung. Respectively Submitted to Thermal Factor and Salt Stress
}

\author{
Amel Sari-Ali Taleb-Bendiab*, Amel Bensouna, Faiçal Hassani, Tawfik Ferouani, \\ Hassiba Stambouli \\ Department of Ecology and Environment, Faculty of Natural Sciences and Life and Earth Sciences and the \\ Universe, University of Tlemcen, Tlemcen, Algeria \\ Email: "talebamel@yahoo.fr
}

Received 21 September 2015; accepted 14 November 2015; published 17 November 2015

Copyright (C) 2015 by authors and Scientific Research Publishing Inc.

This work is licensed under the Creative Commons Attribution International License (CC BY). http://creativecommons.org/licenses/by/4.0/

(c) (i) Open Access

\begin{abstract}
In light of the importance of seeds germinative phase in the progress of later stages of development of any particular plant species in semi-arid and arid area, it is essential to study the germinative behavior and to evaluate the tolerance of a perennial halophyte of Amaranthacaea family, Arthrocnemum glaucum (Del.) Ung. during this crucial phase. A study is devoted to this species seeds germination, which although it's a mandatory halophyte, it's less tolerant to salt stress in germination' phase. Germinative tests are carried out in laboratory, on seeds putted in Petri dishes placed at different temperatures. They enable us to determine the optimal germination temperature, which is $40^{\circ} \mathrm{C}$ while the cold one $\left(5^{\circ} \mathrm{C}\right)$ completely inhibits it. The seeds of Arthrocnemum glaucum show an optimum germination of $44 \%$ in distilled water $(\mathrm{NaCl} 0 \mathrm{~mm})$ similar to glycophytes but they differ in their ability to germinate at higher salinities. Beyond $300 \mathrm{mM}$ germination is completely inhibited. Prior to break dormancy seeds, a cold treatment at $5^{\circ} \mathrm{C}$ has been achieved; the germination capacity of the seeds increases with the duration of the cold treatment. It increases from $30 \%$ after 2 weeks of treatment to $80 \%$ after a treatment of 27 weeks.
\end{abstract}

Keywords

Arthrocnemum glaucum, Halophilic Vegetation, Germination, Salt Stress, Oran (Algeria)

\footnotetext{
${ }^{*}$ Corresponding author.
}

How to cite this paper: Taleb-Bendiab, A.S.-A., et al. (2015) Germination Behaviour of a Perennial Amaranthaceae of North Western Algeria (Oran): Arthrocnemum glaucum (Del.) Ung. Respectively Submitted to Thermal Factor and Salt Stress. Open Journal of Ecology, 5, 544-551. http://dx.doi.org/10.4236/oje.2015.511045 


\section{Introduction}

Halophilic plant species are multi-purpose and have an important ecological interest since they allow the settlement of marginal zones which have a certain constraint on the development of most glycophytes. Today they are at serious risk because of the sharp decline of the natural environment, by human actions, hence the interest of researchers find solutions favoring their regeneration. Knowing that the first critical phase of regeneration is germination, this work aims to study the germination capacity of Arthrocnemum glaucum, subject respectively to thermal factor and to salt stress. These both extrinsic parameters are essential and crucial in the study of phenomena germination species growing in salt-affected environments. Zia and Khan [1] confirm it, temperature and salinity interact to affect the germination of halophytes. According to Pujol et al. [2] seeds germination in saline environments usually occurs in spring or in a season with heavy rainfall, when soil salinity is reduced.

Arthrocnemum glaucum is a perennial subshrub belonging to the Amaranthaceae family [3], which trains hyperhalophilic groups colonizing temporarily submerged environments [4] and [5], such as Chotts and Sebkhas. "Sebkha" is an Arabic word that refers to closed depression with impervious bottom, temporarily occupied by a salt lake and or salt crust; evaporites specialists use it in a more restricted sense of a coastal area located above mean tide level (supra tidal ) in which operates evaporite interstitial crystallization process [6].

Also, Arthrocnemum glaucum is very present as belts at the Sebkha of Oran (Northwest Algeria) (Figure 1).

This shrubby chamaephyte with woody stems at the base, lying down, straightens to bear curious vertical hinged branches with short internodes, which get partially renewed during the year [7]. First fleshy and bluish green than yellowish green, they turn red in autumn (Figure 2), dry and turn brown.

Hidden by persistent calyx, fruits are achenes included in the swollen perianth with membranous or \pm indurated pericarp. Their shell gets thinner and tears at the base, leaving protrude a compressed, elongated and blackish seed (Figure 3(a), Figure 3(b)). The seed of 0.65 to $0.9 \mathrm{~mm}$ is drawn ovoid, shiny brown—black with crustacean, smooth or warty integument with abundant and fleshy albumen; the embryo is dorsal, arched with infer radicle [8].

\section{Materials and Methods}

\subsection{Biological Material}

Seeds, on which germination tests have been carried out, were collected during the autumn at a study station
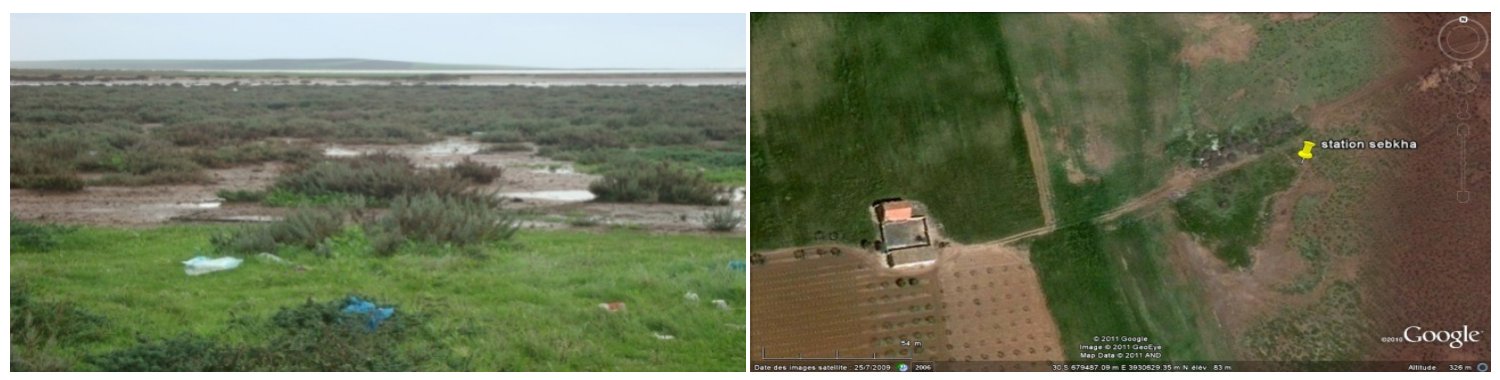

Figure 1. General overview and satellite image of the study station $<$ Sebkha $>$. 8 : Study station.

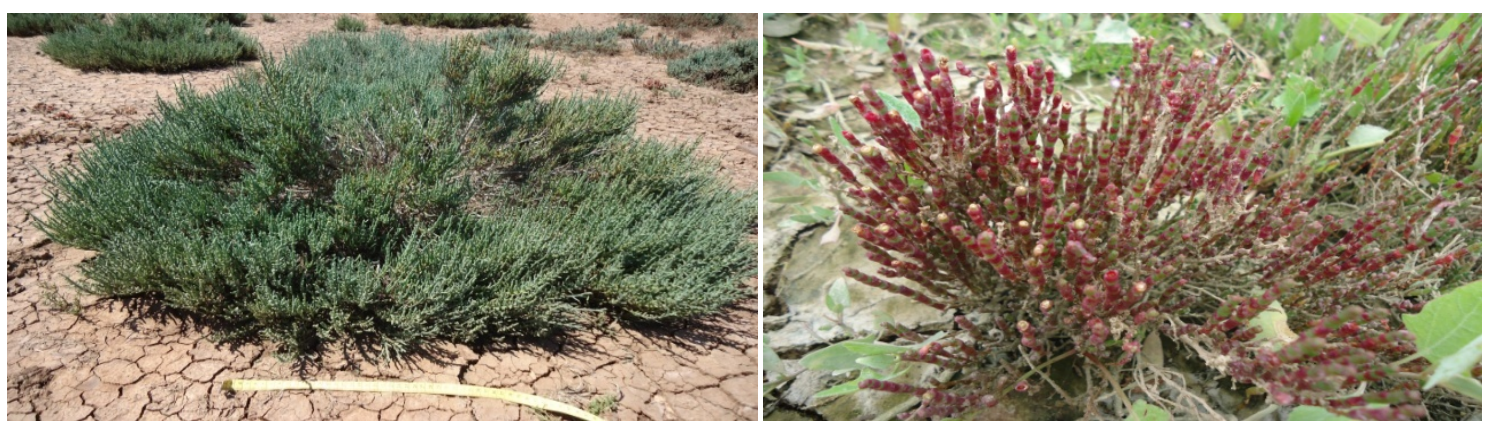

Figure 2. Arthrocnemum glaucum yellowish green aspect than red. 


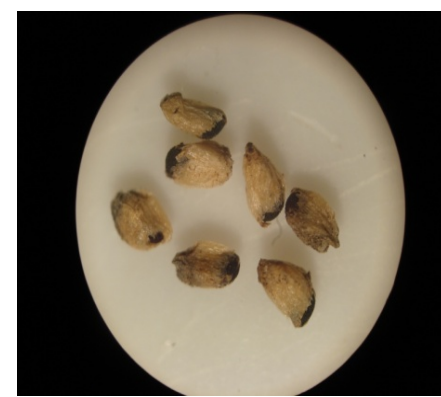

(a)

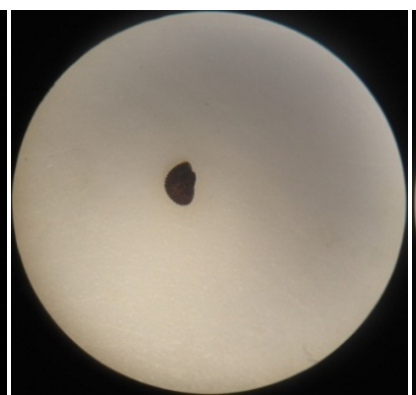

(b)

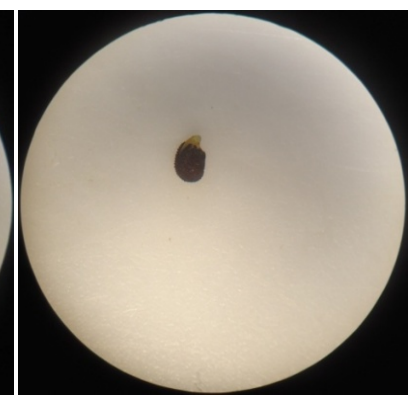

(c)

Figure 3. Arthrocnemum glaucum seed with shell (a) and without shell (b) (c).

"Sebkha" of Oran (Northwest Algeria) located in semi arid bioclimatic level with hot winters according to "Emberger" "climagramme” [9].

\subsection{Method}

The seeds were manually separated from inflorescences and sorted using a binocular microscope as their small size. Only intact seeds and considered ripe were selected for counting. Having sorted the seeds we put them in the fridge for up dormancy by cold treatment. We superficially sterilized seeds by placing them for 5 minutes in a sodium hypochlorite solution and then we have well rinsed them with sterile distilled water.

Each germination test is conducted in five repetitions of 10 seeds each. Seeds intended to germinate are arranged in Petri dishes of $9 \mathrm{~cm}$ diameter containing a layer filter paper soaked in distilled water $(4 \mathrm{ml})$ or $\mathrm{NaCl}$ solution (4 ml) at various concentrations. The germinated seeds are counted and recorded. A seed is considered to have germinated when the radicle had pierced the integument [10] (Figure 3(c)). The observations of seeds were made every day and the Petri dishes were sprayed as necessary. The germination test took place over 28 days. To determine the optimum temperature species germination, the tests are conducted at $5^{\circ} \mathrm{C}$ (in the refrigerator), at the laboratory ambient temperature $\left(18^{\circ} \mathrm{C}-20^{\circ} \mathrm{C}\right)$ and at $30^{\circ} \mathrm{C}$ and $40^{\circ} \mathrm{C}$ (in oven) after seeds cold treatment that lasted two weeks.

The trial was continued on seeds that remained longer in cold (2 months). These seeds were put germinated with sodium chloride at varying concentrations ( $\mathrm{NaCl}$ ): $0 \mathrm{mM}$ (control), $50 \mathrm{mM}, 100 \mathrm{mM}, 200 \mathrm{mM}, 300 \mathrm{mM}$, $400 \mathrm{mM}, 500 \mathrm{mM}, 600 \mathrm{mM}, 700 \mathrm{mM}, 800 \mathrm{mM}, 900 \mathrm{mM}$ to $1000 \mathrm{mM}$. The Petri dishes were incubated at the optimal germination temperature.

\section{Results and Interpretations}

The effect of temperature, $\mathrm{NaCl}$ on germination and the effect of cold treatment duration on seeds were studied for each of the following parameters:

- Final germination rate expressed by the number of germinated seeds to the total number of seeds;

- Germination kinetics to identify growth germination function of time;

- Germination speed used here as the mean germination time (TMG)

$$
\mathrm{TMG}=\frac{\sum n}{\sum(n \cdot j n)} \times 100
$$

with: $n$ the number of germinated seeds the day $j$ and $j n$ the number of days after seeding;

- Average daily germination (MDG = Mean Daily Germination) is, according to Osborne and Nercer [11], the percentage of final germination/number of days the final germination.

To compare the average germination capacity, we conducted the comparison of averages by Khi-squared test at the 5\% using SPSS 20 software. To each average is assigned a letter (e.g. A, B, C, D or E) and values with the same letter do not differ at the $5 \%$ threshold ( $p \leq 0.05$ significant difference).

\subsection{Effect of the Temperature on Germination}

The results (Figure 4) show an optimum germination for seeds germinated in distilled water and placed in a 


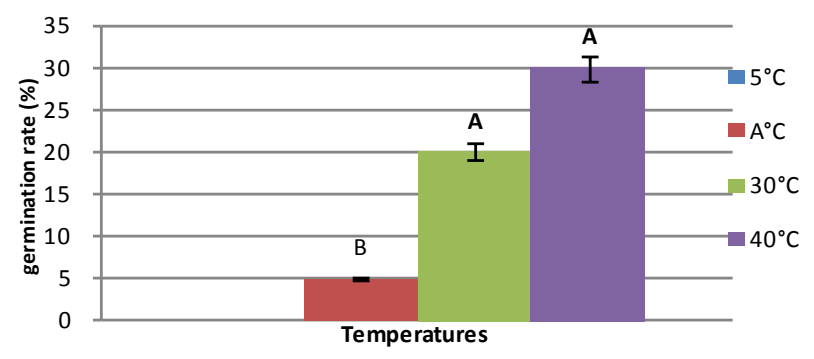

Figure 4. Variation of seeds germination rate as a function of temperature. $\quad \mathrm{A}^{\circ} \mathrm{C}=18^{\circ} \mathrm{C}-20^{\circ} \mathrm{C}$.

temperature equal to $40^{\circ} \mathrm{C}$. The cold seems to cause complete inhibition of germination.

At $40^{\circ} \mathrm{C}$ seed germination occurred after one day which shows us the speed of germination of Arthrocnemum glaucum seeds and therefore a form of adaptation to extreme environments (Figures 5-7).

\subsection{NaCl Effect on Germination}

Figure 8 below shows the effect of $\mathrm{NaCl}$ on the seeds germination rate of the species studied. For the control concentration $(0 \mathrm{mM} \mathrm{NaCl})$, the seeds germination rate is around $44 \%$. The salinity significantly reduced germination of these seeds (21\%) at the lowest dose of $\mathrm{NaCl}$ applied so $50 \mathrm{mM}$. The $\mathrm{NaCl}$ tolerance of these seeds is $300 \mathrm{mM}$ with a rate of $2 \%$. Above this limit, the germination was completely inhibited.

Figure 9 shows that the curves of the germination percentage of seeds, putted to germinate on different concentrations of $\mathrm{NaCl}$, are located below the control curve and approach zero gradually as the dose of $\mathrm{NaCl}$ increases. It also reveals a slow and delayed germination process (Figure 10 and Figure 11).

All of these interpretations have been confirmed by several authors as Katembe et al. [12] or Bajji et al. [13]: An increase in salt stress induces both a reduction in the percentage of seeds germination and a delay in the initiation of the germination process [14]-[16], but can also cause complete inhibition of germination process at salinities beyond the tolerance limits of the species [17].

The failure of germination under saline conditions was attributed by some authors to the lowering of the soil water potential and/or to an ionic toxicity [16]; but recently this effect has also been attributed to oxidative stress induced by salinity [17].

Also, the germination of many halophytes occurs at times when there is an optimum combination of day length, temperature regime and salinity [1].

\subsection{Effect of Seeds Cold Treatment $\left(5^{\circ} \mathrm{C}\right)$ Duration}

Figure 12 shows that the germination capacity of seeds increases with the duration of the cold treatment $\left(5^{\circ} \mathrm{C}\right)$. It increased from $30 \%$ after 2 weeks of treatment to $80 \%$ after treatment for 27 weeks. Figure 13 shows the evolution of the germination time (28 days) for each of three cold treatments. The results show that the curve of 27 weeks of cold treatment is significantly off the other two and that, from the first days of the trial. 3 phases are observed: a lag phase, a substantially linear phase corresponding to a rapid increase in germination, a phase step representing the final germination percentage.

The data in Figure 14, illustrating the effect of the duration of cold treatment $\left(5^{\circ} \mathrm{C}\right)$ on the rate of germination, expressed by the daily germination time, show that the increase of the duration of cold treatment causes a marked reduction in average time germination (less than 2 days) whereas in Figure 15, the average per day of germination (\%) increases (3\%).

\section{Conclusions}

The results reported in this study show that Arthrocnemum glaucum is a halophyte sensitive to the action of temperature and salinity at the stage of germination.

The optimum germination temperature is $40^{\circ} \mathrm{C}$ and any temperature reduction inhibits germination.

The final germination and germination rate linearly decreases with increasing salt concentrations. Although it is a halophyte, it turns out that Arthrocnemum glaucum is very sensitive to salt; it manifests salt stress in germi- 


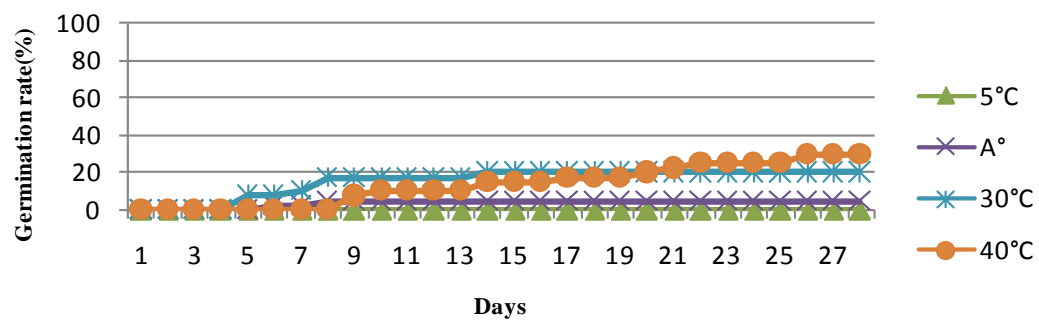

Figure 5. Kinetic seeds germination as a function of temperature. $\quad \mathrm{A}^{\circ} \mathrm{C}=$ $18^{\circ} \mathrm{C}-20^{\circ} \mathrm{C}$.

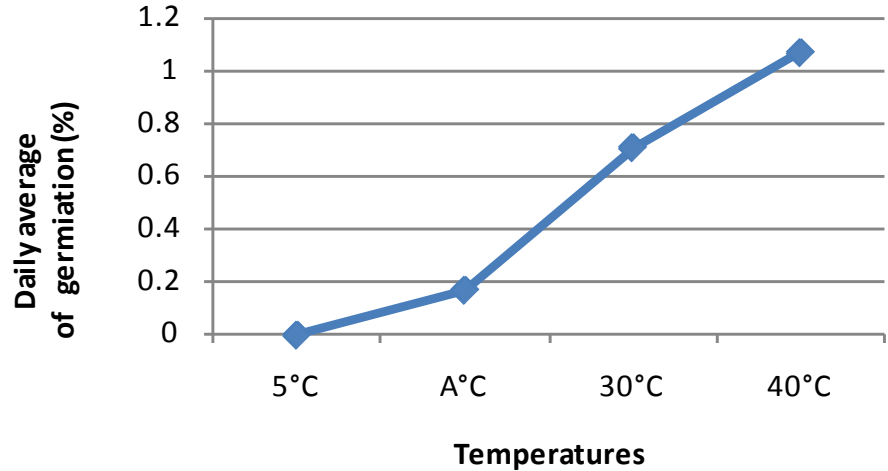

Figure 6. Variation of the daily average of germination as a function of temperature. $\mathrm{A}^{\circ} \mathrm{C}=18^{\circ} \mathrm{C}-20^{\circ} \mathrm{C}$.

\section{TMG}
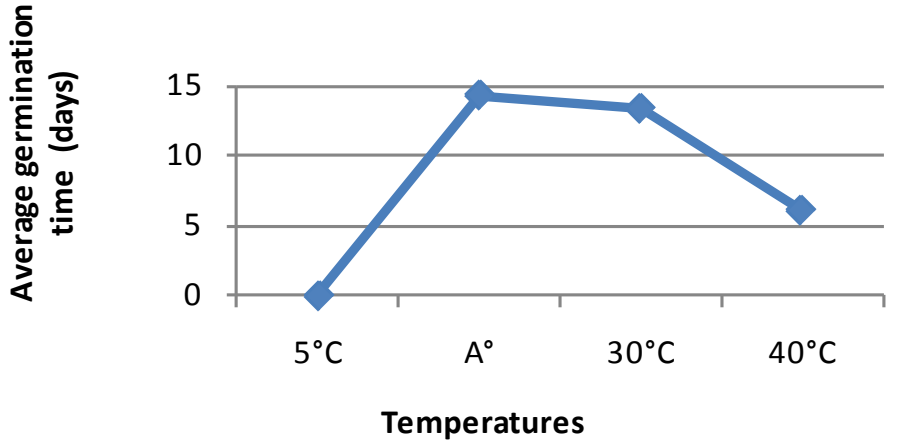

Figure 7. Variation in average germination time as a function of temperature. $\mathrm{A}^{\circ} \mathrm{C}$ $=18^{\circ} \mathrm{C}-20^{\circ} \mathrm{C}$.

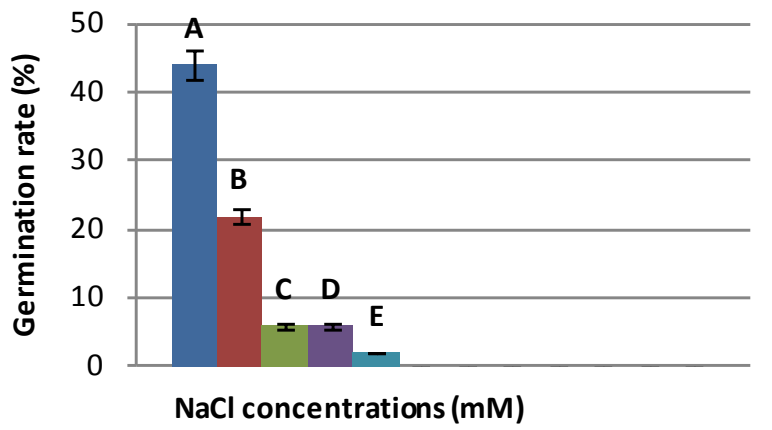
- 0
50
- 100
- 200
300
400
500

Figure 8. Variation of seeds germination rate as a function of salt stress. 


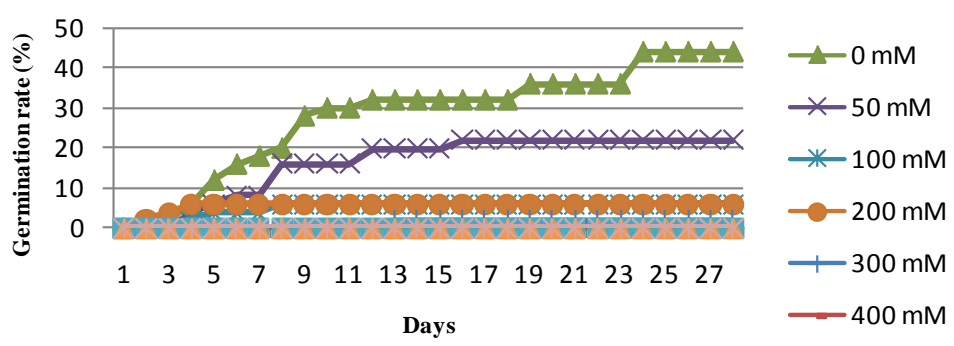

Figure 9. Kinetics of seeds germination as a function of salt stress.

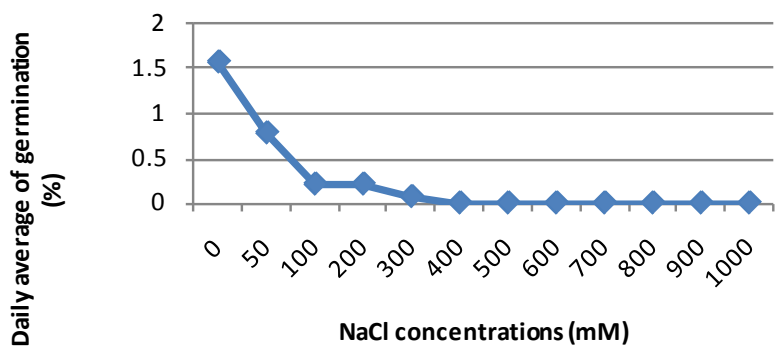

Figure 10. Variation of the daily average of germination as a function of $\mathrm{NaCl}$ concentrations.

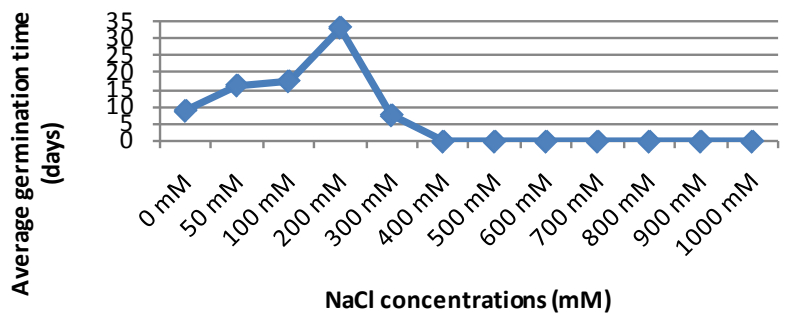

Figure 11. Variation of average germination time as a function of $\mathrm{NaCl}$ concentrations.

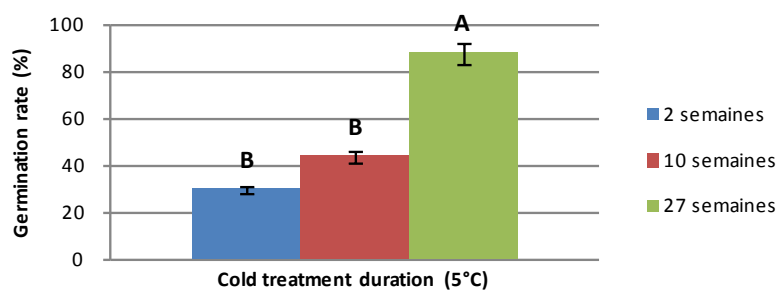

Figure 12. Variation of the germination rate of seeds as a function of seeds cold treatment $\left(5^{\circ} \mathrm{C}\right)$ duration.

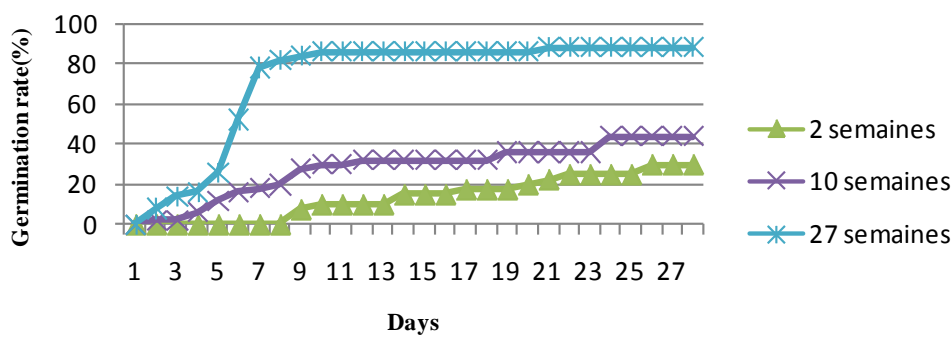

Figure 13. Kinetics of germination as a function of the seeds cold treatment $\left(5^{\circ} \mathrm{C}\right)$ duration. 


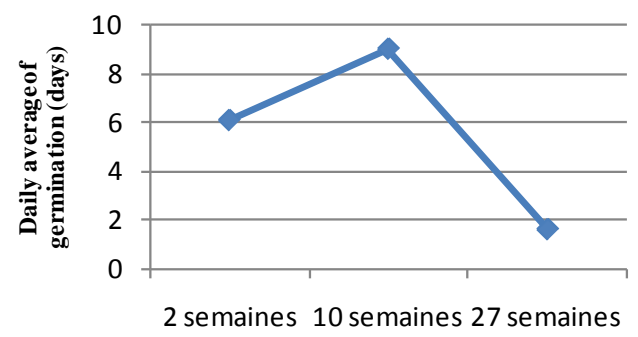

Figure 14. Variation of the daily average of germination as a function of cold treatment $\left(5^{\circ} \mathrm{C}\right)$ duration.

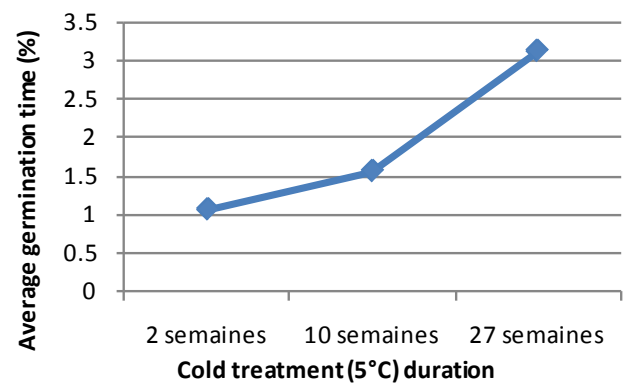

Figure 15. Variation of average germination time as a function of cold treatment $\left(5^{\circ} \mathrm{C}\right)$ duration.

nation phase and prefers to germinate in distilled water. This result shows that it is difficult to link salt tolerance during germination to the species ecology or to its tolerance at the adult plants stage.

According to Dell'aquila and Spada [18], salinity can activate or stimulate the genesis of some proteins during germination. Thus, the halophytes have seeds rich in proteins, oils and carbohydrates that can provide tremendous value to alternative crops in agricultural areas affected by salinity [19]. Specifically, Arthrocnemum glaucum deserves special attention in biodiversity conservation efforts, as it has great ecological plasticity and can be used for development projects and rehabilitation of degraded marginal ecosystems. This study should be extended to other halophytes especially as, according to Wetson et al. [20], on a total of about 2400 halophilic species reported by Lieth et al. [21], the germination data are , however, only available for a few hundred species.

\section{Acknowledgements}

The authors would like to express their thanks to Youcef Senoussaoui, specialist in Epidemiology, E.P.S.P. of Sebdou (Algeria) and to Mohammed El-Amine Ghembaza, Internal Medicine Department, CHU Tlemcen (Algeria).

\section{References}

[1] Zia, S. and Khan, M.A. (2004) Effect of Light, Salinity and Temperature on the Germination of Limonium stocksii. Canadian Journal of Botany, 82, 151-157. http://dx.doi.org/10.1139/b03-118

[2] Pujol, J.A., Calvo, J.F. and Díaz, L.R. (2000) Recovery of Germination from Different Osmotic Conditions by Four Halophytes from Southeastern Spain. Annals of Botany, 85, 279-286. http://dx.doi.org/10.1006/anbo.1999.1028

[3] Angiosperms Phylogeny Group (2003) An Update of the Angiosperms Phylogeny Group Classification for the Orders and Families of Flowering Plants: APG II. Botanical Journal of the Linnean Society, 141, 399-436. http://dx.doi.org/10.1046/j.1095-8339.2003.t01-1-00158.x

[4] Corre J.J. (1975) Caractéristiques du Milieu salé. Vie et Milieu, 26, 197-245.

[5] Metge, G. (1977) Etude Synécologique de la Dépression du Vigniérat (B.d.R). Thèse de Doctorat, Université des Sciences, Aix-Marseille III, 464 p.

[6] Rouchy, J.M. and Blanc-Valleron, M.M. (2009) Les Evaporites Matériaux Singuliers, Milieux Extrêmes. Vuiber 6, 184 
p.

[7] Vignes, P. and Vignes, D. (2007) L’herbier des Plantes Sauvages. Edition Larousse, France, 565 p.

[8] Maire, R. (1962) Flore de l’Afrique du nord. Vol. 8, Edition Lechevalier, France, 97-99.

[9] Emberger, L. (1945) Climate Biogeographic Classification. Vol. 7, Collection of Botanical Geological and Zoological Laboratories Works, Montpellier Faculty of Sciences, 3-43.

[10] Grouzis, M., Berger, A. and Heim, G. (1976) Polymorphisme et Germination des Graines chez trois Espèces Annuelles du Genre Salicornia. Plant Ecology, 11, 41-52.

[11] Osborne, J.M., Fox, J.E.D., Mercer, S., Lieth, H. and Al Masoom, A. (1993) Towards the Rational use of High Salinity Plants, 1: 323-338. Kluwer Academic Publishers, Dordrecht, 521 p.

[12] Katembe, W.J., Ungar, I.A. and Mitchell, J.P. (1998) Effects of Salinity on Germination and Seedling Growth of Two Atriplex Species (Chenopodiaceae). Annals of Botany, 82, 167-175. http://dx.doi.org/10.1006/anbo.1998.0663

[13] Bajji, M., Kine, J.M. and Lutts, S. (2002) Osmotic and Ionic Effects of NaCl on Germination, Early Seedling Growth, and Ion Content of Atriplex halimus (Chenopodiaceae). Canadian Journal of Botany, 80, 297-304. http://dx.doi.org/10.1139/b02-008

[14] Breen, C.M., Everson, C. and Rogers, K. (1977) Ecological Studies on Sporobolus virginicus (L.) Kunth with Particular Reference to Salinity and Inundation. Hydrobiologia, 54, 135-140. http://dx.doi.org/10.1007/BF00034987

[15] Zid, E. and Boukhris, M. (1977) Some Aspects of Salt Tolerance of Atriplex halimus L.: Multiplication, Growth, Mineral Composition. Oecologia Plantarum, 12, 351-362.

[16] Pujol, J.A., Calvo, J.F. and Díaz, L.R. (2000) Recovery of Germination from Different Osmotic Conditions by Four Halophytes from South Eastern Spain. Annals of Botany, 85, 279-286. http://dx.doi.org/10.1006/anbo.1999.1028

[17] Khan, M.A. and Rizvi, Y. (1994) The Effect of Salinity, Temperature and Growth Regulators on the Germination and Early Seedling Growth of Atriplex griffithii Moq. Var. Stocksii Boiss. Canadian Journal of Botany, 72, 475-479. http://dx.doi.org/10.1139/b94-063

[18] Dell'Aquila, A. and Spada, P. (1993) The Effect of Salinity Stress upon Protein Synthesis of Germinating Wheat Embryo. Annals of Botany, 72, 97-101. http://dx.doi.org/10.1006/anbo.1993.1085

[19] Shepherd, K.A., Macfarlane, T.D. and Colmer, T.D. (2005) Morphology, Anatomy and Histochemistry of Salicornioideae (Chenopodiaceae) Fruits and Seeds. Annals of Botany, 95, 917-933. http://dx.doi.org/10.1093/aob/mci101

[20] Wetson, M., Cassaniti, C. and Flowers, T.J. (2008) Do Conditions during Dormancy Influence Germination of Suaeda maritima. Oxford University Press, Oxford, 1319-1327.

[21] Lieth, H., Moschenco, M., Lohmann, M., Koyro, H.W. and Hamdy, A. (1999) Halophyte Uses in Different Climates. I. Ecological and Ecophysiological Studies. In: Lieth, H., Ed., Progress in Biometeriology, Backhause, Leiden. 